DOI 10.37491/UNZ.75-76.2

УДК 37:578.834.1

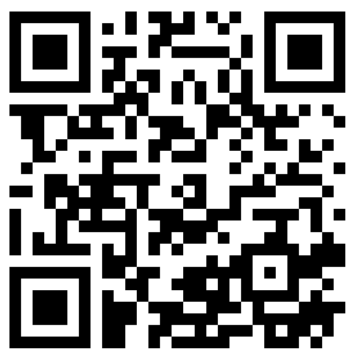

Nicoleta DOSPINESCU ${ }^{1}$, Octavian DOSPINESCU ${ }^{2}$

\title{
INFORMATION TECHNOLOGIES TO SUPPORT EDUCATION DURING COVID-19
}

The purpose of this research is to make a synthesis of the literature on the implementation of information and communication technologies (ICT) in the educational environment, taking into account the advantages and disadvantages, benefits and limitations, attempts to overcome the COVID-19 pandemic, as well as the current needs generated by social distancing. Both the educational and technical components necessary to create and maintain Internet platforms for communication and evaluation are taken into account. The fact that new technologies related to artificial intelligence, robotics, cloud computing and blockchain are progressing rapidly makes Romania accelerate its digital transformation process in accordance with the requirements of the European Union. From now on, every person, especially young people, should constantly improve their digital skills throughout their lives. In fact, the progress in the implementation of technologies in education has been insignificant. Young people tend to use the Internet more to socialize and less to educate themselves. Improvement of results in youth education can be achieved only by innovative teaching systems, based on new services, technologies, competencies of teachers that set clear teaching objectives. It was noted that some as-

\footnotetext{
${ }^{1}$ Assoc. Prof., PhD,

University Alexandru Ioan Cuza, Iasi, Romania dnicole@uaic.ro,

https://orcid.org/0000-0002-7097-7365.

${ }^{2}$ Assoc. Prof., PhD,

University Alexandru Ioan Cuza, Iasi, Romania doctav@uaic.ro,

https://orcid.org/0000-0002-5403-8050.
}

(C) Dospinescu N., Dospinescu O., 2020 
pects of this study were presented at the XX International Scientific and Practical Conference "Statistical Methods and Information Technologies for Analysis of Socio-Economic Development", which took place on May 21, 2020 at Leonid Yuzkov Khmelnytsky University of Management and Law.

Keywords: information and communication technology, media pedagogy, COVID-19, online education, social distancing.

\section{Introduction}

The personal development and the specific competencies necessary in the professional, educational, but also in the social activities require more and more the use of information and communication technology (ICT). Although the younger generations naturally tend to everything that is new, the mature ones still resist change. But the fact that these information technologies are intuitive and easy to use makes these mature generations not indifferent.

The increasingly important place occupied by new technologies in everyone's lives determines the decision makers to understand how their use would help in the development of the educational system, to the detriment of the classic textbooks, the worksheet, the experiences from the real workshops / laboratories. The European Union has set itself the objective of research in the field of Information and Communication Technologies, in the Seventh Framework Program (FP7), to increase the competitiveness for European TIC industry so that it can model and control its evolution in relation to the requirements of the economy and society.

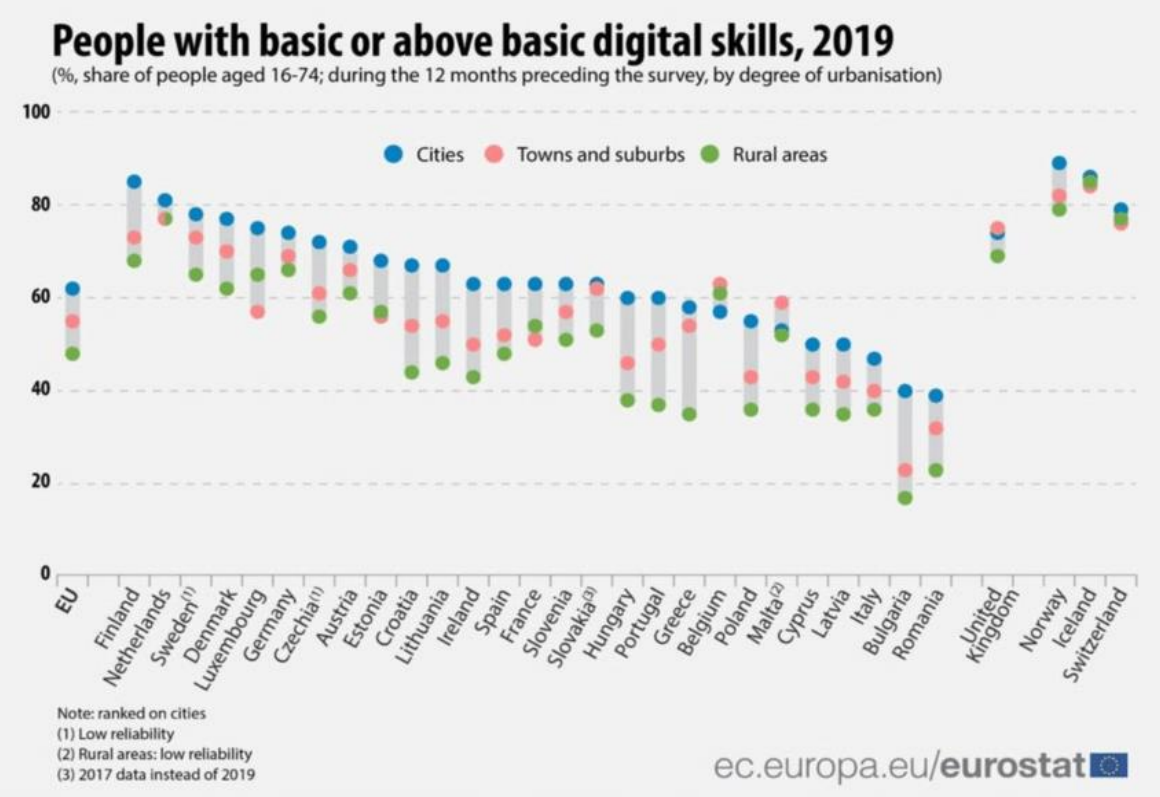

Source: Eurostat, 2019 [1]. 
At the level of 2019 , only $11 \%$ of the Romanian population aged 16-74 have demonstrated digital skills at an acceptable level. This fact made Romania the 1st place in the European Union in terms of the need to improve digital skills, followed by Bulgaria. The existing EU economy and society index shows that $42 \%$ of the EU population does not have basic digital skills. The presence of experts in the digital field is constantly and continuously demanded on the labor market, exiting a deficit of theirs.

The emergence of the global Covid-19 pandemic has accelerated the implementation of new technologies in youth education by teachers in various institutions. This Pandemic has also produced a greater awareness of the major differences in digital skills, connectivity and the usefulness of technologies in education. The crisis has highlighted the opportunities and risks of online activities. He also pointed out the need to support the development, education and security of young people in the online environment.

The European Agenda for Action on Sustainable Competitiveness, Social Equity and Resilience was also included in the European Agenda for Action on Digital Education (2021-2027). It was based on a study of more than 60 countries and more than 2,700 contributions [2] to which the Romanian specialists also contributed with 1576 answers (58\%). The results of the study showed that over $60 \%$ of respondents did not use distance and online learning tools before the crisis; $95 \%$ of respondents believe that this crisis will lead to an irreversible change in modern education; over $60 \%$ believe that they have significantly improved their digital skills during the Pandemic.

At the structural level, the Digital Education Action Plan has as strategic priorities:

1. Development of a high quality digital educational ecosystem

2. Strengthening digital skills for digital transformation.

The creation of the European area of digital education provided for in the European Agenda aims at the formation and development of digital and transversal competences, as well as gender inclusion and equality, the training of teachers, the strengthening of international cooperation in education and training.

\section{Media pedagogy. Challenges}

We are now witnessing the formation of a new education, also called media pedagogy. The way of scientific and social knowledge is considerably based on online and the information technologies offered. Teachers, students, students, managers, artists, athletes and other categories, as well as those responsible for information technology face the biggest challenge of their careers. From the point of view of those responsible for the technology, the problems appear due to the dysfunction at the level of the infrastructure, the «denial of service» type attacks or sites that fall due to the heavy traffic.

Other challenges in online "teaching-learning" include a lack of predictability; the heterogeneous school network characterized by a very large gap between educational institutions; insufficient development of digital skills that caused the lack of organization of the teaching process in the 
online environment; reduced internet connectivity and accessibility; the lack of technological possibilities in many of the Romanian families, which complicates the teaching process in the online environment.

The Digital Agenda Romania 2020 contains as Strategies regarding the digitalization of education, first of all the management and administration part, referring to records, electronic catalogue, reports, communication, highlighting the progress, anonymizing the data. Secondly, it contains aspects related to the didactic activity, the way to do the teaching - learning evaluation. Thirdly, it contains aspects related to counselling and professional orientation activities, socio-psychological-emotional support, but also extracurricular activities; activities that promote excellence; activities aimed at a correct relationship, partnership between school - local administration business environment.

The digitalization strategy of the Romanian education, launched by the Ministry of Education and Research under the name of SMART.Edu, has as priorities:

1. creating accessibility to digital infrastructure for all stakeholders in order to achieve an inclusive education; tal literacy, social equity;

2 . connectivity that involves the open use of educational resources, digi-

3. the community that can be consulted and involved in order to integrate young people in the professions of the future;

4. creating a high-performance digital educational environment, ensured by ethics, data protection;

5. innovation and development of entrepreneurship

6. sustainability and green economy for education

The challenges determine three modes of action:

1. ensuring the stability and continuity of educational, economic and social life;

2. institutionalization of new ways of working;

3. prioritizing the technology transformed by the knowledge accumulated during the crisis and obtaining resilience.

The current conditions lead us to understand the "new normal». The end of the crisis will not mean a complete return to the usual methods. The current crisis, through its characteristics, demonstrates the essential importance of technology and digital channels for almost any organization, be it educational or otherwise.

The contemporary revolution, amid the technological boom and the Covid-19 pandemic, means not only the integration of new technologies but also the various types of extremely abundant information. The capacity for analysis and synthesis is intensely demanded as well as the critical spirit, essential in sorting information. Society has become increasingly dependent on information, its processing and transmission. As a result, the concept of information society appeared, bringing multiple positive effects (Brown T., Wyatt J., 2015) [3] such as: reducing physical and even intellectual effort by automating activities; reduction of data processing and transmission time; increasing performance due to the quality of information. 


\section{Advantages of the New Information Technologies in Education}

The advantages offered by the new information technologies to education are indisputable: quick access to the multiple scientific resources existing in the online databases that help in deepening the studied concepts; open, interactive and interdisciplinary way of teacher-student-student interaction; access to various video materials, tutorials that help in knowing the information and developing online communities of enthusiasts for a certain concept / field. More, other advantages are: quick access to the multiple scientific resources existing in the online databases or the virtual libraries that help in deepening the studied concepts; open, interactive and interdisciplinary way of teacher-student-student interaction; access to various video materials, tutorials that help in knowing the information and developing online communities of enthusiasts for a certain concept / field. Nayar and Kumar (2018) [4] argued that Information and Communication Technology (ICT) removes time and space constraints in higher education and allows access anytime and anywhere. We can also add as a benefit, the specialized learning of tasks; social modeling also takes place through interactive communication on forums, virtual networks or specific communities. To these aspects is added as an advantage, graphic programs that aim at developing the specialized skills of young people, avoiding elements related to language or other barriers. Another benefit is the fast and specific evaluation of the works / applications made by the students; allows distance teaching. Regarding the interactivity of the existing online computer applications and necessary in the educational process, we can mention that the virtual offers useful skills to young people. Presentation programs with specialized Power Point design have an easy standard for presenting specialized knowledge. Also, programs such as Zoom, Moodle, Google Class, etc. offer various possibilities for interactive voice and visual communication, storage and assessment of topics, online assessment of knowledge gained. Wikis is used by many educational organizations (Hany A. I., 2020) [5], facilitating virtual learning and achieving a more collaborative work environment between students and teachers. There is a rapid electronic literacy, accelerated by the need to communicate in conditions of social distance.

In terms of competencies, virtual education systems succeed in helping to develop specialized competencies on a specific topic. The same systems also develop the critical thinking absolutely necessary in this type of non-standard education. Multimedia systems are a social barometer to guide the tendency of young people to certain topics of interest, research areas, to certain types of jobs.

In the current online education system, based on digital technology, skills move easily from teacher to student and vice versa, avoiding the linear form of traditional, one-way education, in which the teacher had a monopoly on communicating the course. The student is no longer a passive spectator, who only assimilates knowledge, now has a dialogue or just-in-time feedback for the applications made. On this occasion, the educational communication 
process undergoes a metamorphosis. The teacher becomes a moderator, a facilitator, a coordinator of the youth education process.

The study conducted by Ilinițchi G. (2020) [6] regarding the effects of the implementation of new technologies and communication systems in education reveals that $85 \%$ of those surveyed acknowledged the increase in intellectual work due to them; $76 \%$ identified an active and responsible attitude; $70 \%$ of respondents noted that collaborative learning is an effective form of training; $79 \%$ of respondents confirmed that they use multimedia technologies in the training process; $82 \%$ confirmed that e-learning is a more effective step of training and goes beyond traditional education, $67 \%$ of respondents confirmed that information technologies help them develop creativity. Also, advantages were identified such as: reduction of time consumption for documentation, use of teaching materials; the possibility of adapting personal education programs, extensive possibilities of interdisciplinary education, decreasing costs by supporting the educational process.

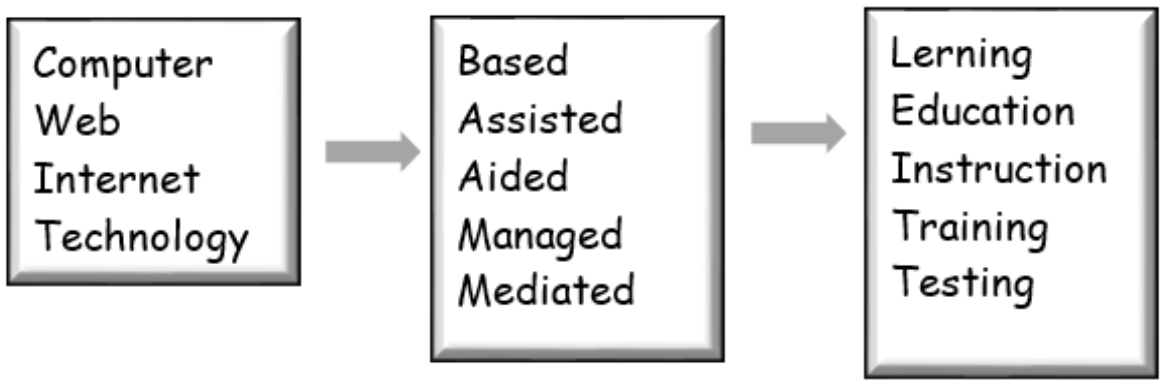

Fig. 1. The impact of information technologies in education

Digitized support materials for presenting concepts in specialized courses combine both text and image (animation) and sound. Hyperlinks provide quick access to related information. The costs of making and maintaining these materials are low, and the data can be updated immediately. The information can be accessed in real time, when the student needs it. Another advantage is related to the storage space that refers only to the computer's memory or to the online areas.

For university institutional development and achieving the expected performance indicators, information and communication technology is essential (Chertok I.R.A et all., 2013) [7] and involves both the creation of software for the teaching process and the design and administration of communication networks and information security. The advantages offered by the use of information systems in the educational activity refer to: the modernization of the teaching-learning-evaluation process; personalized access to information; greater transparency of university processes; development of competition in the university environment. 


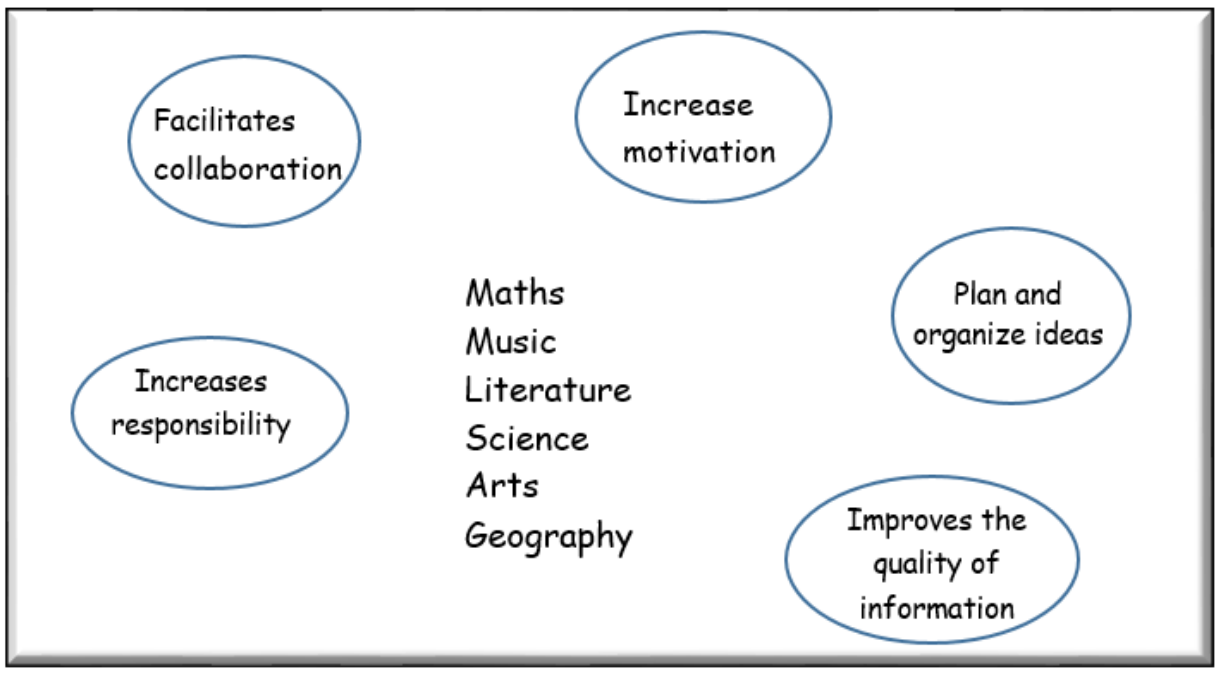

Fig. 2. Advantages of Information Technologies in Education

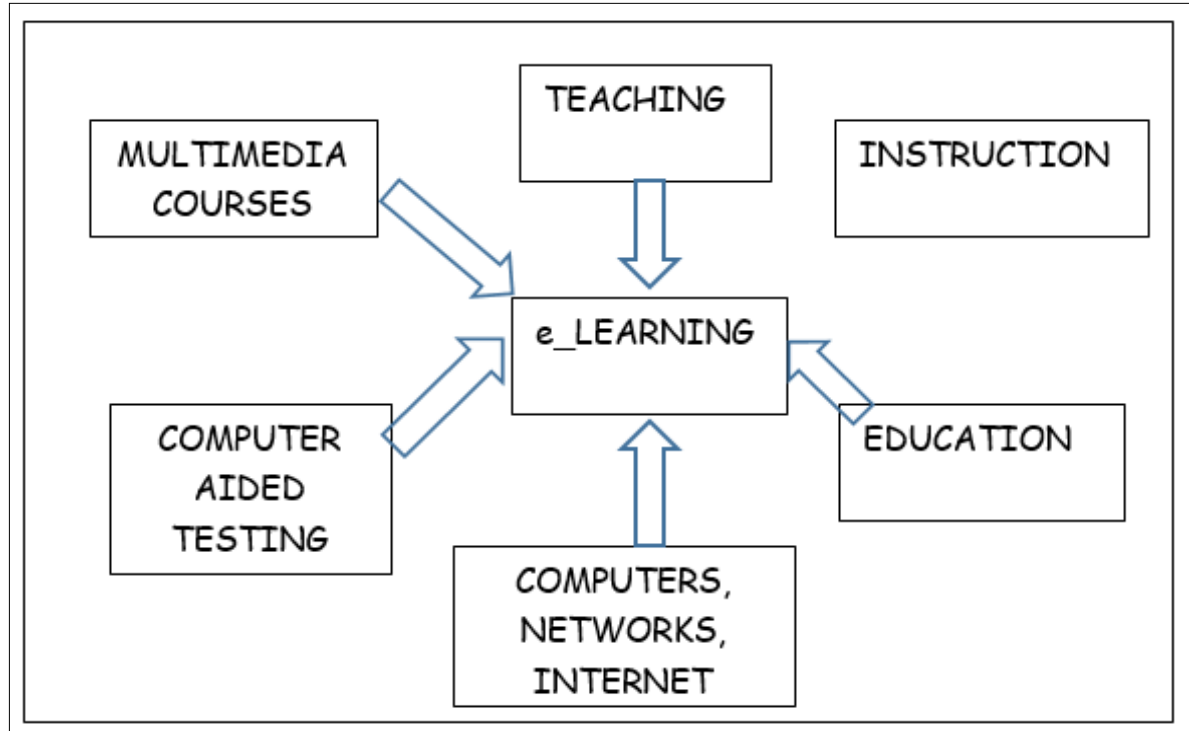

Fig. 3. e-Learning utility

A large number of higher education institutions have adopted some form of social media for educational or promotional purposes. In addition to the websites created, educational institutions have also opted for social networks due to their interactive nature and the ease of creating specific groups (Kang \& Norton, 2006) [8]. 


\section{Some limitation and risks about the ICT used in education}

There are some voices that fight the use of information technologies for instructional and educational purposes. This is because the educational software is accused of simplifying the information so as to require zero effort on the part of the student. It is also noted that articles or documents without scientific basis, or specialized references, could lead to misinformation of students, or even completely wrong. Other observable risks in the case of using information communication technologies are related to: vulnerability regarding the personal data of students and teachers; they should be protected; the risk of cyberbullying (cyberbullying); lack of infrastructure, computers and Internet, in some geographical areas; teachers do not have the necessary skills for distance learning and for the use of virtual and digital means; the appearance of school dropout.

As a key element in the education of young people, teamwork appeared in which students share their skills and competencies in order to have as many chances as possible in obtaining interesting and useful materials, but also for a special experience. Thus, for the teacher it becomes difficult to coordinate and evaluate the work scenario and the intellectual contribution of each participant (Aouine A., Mahdaoui L., 2020) [9]. Even if technology provides a set of tools to communicate, coordinate and collaborate, I ask the questions: "What should be the individual and collective performance criteria in evaluating a result obtained in the team?»; "How to evaluate and measure the effectiveness and added value of these activities in a professional setting?»; "How can subjectivity be eliminated?». In addition to the six principles of group work assessment set out in Galton (2010) [10], "a fair system should be used that rewards both individual effort and group collaboration.» From a didactic point of view, it is appreciated that the evaluation of the work results of a group of young people does not reflect the quality of each member of the team because certain deficiencies of some members can be covered by the competencies of others. The authors Aouine A., Mahdaoui L. (2020) [9] propose a combined system on education management and workflow in the online environment.

Other observable risks in the case of using information communication technologies are related to: vulnerability regarding the personal data of pupils, students and teachers; they should be protected; the risk of cyberbullying (cyberbullying); lack of infrastructure, computers and Internet, in some geographical areas; teachers do not have the necessary skills for distance learning and for the use of virtual and digital means; the appearance of school dropout.

\section{Perspectives of the development of information technologies for education}

ANIS's vision in the project «Digital Romania 2025» (Anis, 2020) [11] is based on very useful and specific objectives such as: growing the IT sector up to $10 \%$ of Gross Domestic Product and generating an important HUB of information technology in Central Europe and East. It is also desired to develop 
a fiscal framework to support the acceleration of the digital economy and the improvement of the results in the PISA tests by 5 positions.

The Covid-19 crisis was a very good test that showed how important digital information technologies are in both education and economics and therefore their development is not an option but a necessity, a "must have». In addition to the development of «Startup Nation» type programs, the attraction of private investors in the Romanian high-tech industry is the involvement of higher education and research in the university environment to innovate new computer programs dedicated to both education and business.

The digitization process has been supported by the European Union since 2014, and the result, progress, is monitored by the Sustainable Economy and Society Index (DESI). These indices did not rank Romania on the most favorable place and for this reason the projects and activities proposed for digitization until 2025 keep all the component indicators of DESI. It is desired to perform an analysis of disaggregated connectivity per stratum in order to determine the amount of investment, but also how these investments are interconnected, integrated. Programs aimed at making investments in technology correlated with those that help educate the community. Digitization is meant to help the learning process. Globally, we want to transform the role of the teacher from information provider to mentor of pupils and students, who become active learners. Education will be based on pedagogical principles useful for the 21st century such as: critical thinking, creativity in solving problems, team collaboration, all of which have as a binder the technology dedicated to learning. According to the World Economic Forum, $65 \%$ of the professions of the current generation of pupils and students will be created in the coming years, so they do not exist now, and the school must prepare them to be flexible and to mold them. Digitization gives education ubiquity. Digital technologies have proven their effectiveness during the Covid-19 pandemic, saving the educational process and demonstrating the need to transform education into a digital one.

First and foremost, the development of a high-speed internet infrastructure to which all educational centers have access is envisaged. It is also desired to develop work platforms that respect data confidentiality and ethical standards. Modernization of the education program so as to place great emphasis on the development of skills for the use of digital technology from an early age. Also, the use of teaching materials to include existing audiovideo information in digital format and these can be displayed both in class and on various online platforms.

The aim is also to interconnect digital communication platforms at European level, Cloud EU, in order to strengthen the EU's position in the area of innovation, education, competitiveness in order to create the Digital Single Market.

The higher education system connects and adapts to EU strategies to include digitalisation in the teaching-innovation-evaluation process. It also wants to connect with business organizations in order to establish partnerships to simplify the integration of graduates in the new form of market economy (Bercu A, et. al, 2020) [12]. The research carried out at the academic 
level is intended to be correlated with the existing needs in the social, commercial area in order to accelerate sustainable development.

\section{Conclusions}

However, there are scientific studies (Ashraf M., Hoque R., 2016; Donner J., Toyama K., 2009) [13; 14] that show that the application of information technology in education is one of the main factors in the development of a nation. Information technology is considered important for communication and distance education, but it is intended to be used in the short term, as a temporary solution. It is considered that the direct teacher-student / student interaction in the classroom is essential for school / university life and can be achieved even in those areas without infrastructure.

We conclude that, although there are certain opposable aspects between the two education systems, the traditional one and the one based on digital technology, they can still be completed, when the social distance imposed by the regulations on Covid-19 will disappear. The multiple advantages of the new educational system, based on ICT, are important and deserve to be capitalized, bringing added value to the traditional system based on human interaction, often essential.

\section{References}

1. Hinsenkamp, M.; Rigler, D.; Stepankova,O.; Shah, H.; Gialelis, Y.; Pierce, R.; $\quad$ Celentano, U.; $\quad$ Zhitomirsky-Geffet, M.; $\quad$ Vallverdú, J.; Özdemir, D. (2020). Guidelines for Diverse Citizen Science Recruitment (Version 5.3). Retrieved from Zenodo. https://doi.org/10.5281/zenodo.3923820.

2. Digital education action plan (update). (N.d.) Retrieved from European Commission: http://bit.ly/30Iooff.

3. Brown, T., \& Wyatt, J. (2015), Design thinking for social innovation. Annual Review of Policy Design, 3 (1), 1-10. Retrieved from: http://bit.ly/2NlXveg.

4. Nayar, K. B., \& Kumar, V. (2018). Cost benefit analysis of cloud computing in education. International Journal of Business Information Systems, 27 (2), $205 . \quad$ Retrieved from: https://bit.ly/3bL973I. https://doi.org/10.1504/ijbis.2018.10009814.

5. Ismail, H. A. (2020). Users' Intention to Share Knowledge Using Wiki in Virtual Learning Community. International Journal of Information and Communication Technology Education (IJICTE), 16 (1), 1-15. https://doi.org/10.4018/IJICTE.2020010101.

6. Ilinițchi, G., Prodan, A. (2020), Implementarea tehnologiilor informaționale şi asistemelor de comunicare în educaţie, Chişinău. Retrieved from Universitatea de Stat de Educatie Fizica si Sport: https://bit.ly/3tgkQgv.

7. Chertok, I. R. A., Barnes, E. R., Gilleland, D. (2014), Academic integrity in the online learning environment for health sciences students. Nurse Education Today, 34 (10), 1324-1329. https://doi.org/10.1016/j.nedt.2013.06.002.

8. Kang, S., Norton, H. E. (2006) Colleges and universities' use of the World Wide Web: A public relations tool for the digital age. Public Relations Review, 32 (4), 426-428. https://doi.org/10.1016/j.pubrev.2006.08.003.

9. Aouine, A., \& Mahdaoui, L. (2020) Integration of Examination Strategies in E-Learning Platform for Assessment of Collaborative Activities. Inter- 
national Journal of Information and Communication Technology Education (IJICTE), 16 (1), 30-49. https://doi.org/10.4018/IJICTE.2020010103.

10. Bangs, J., Macbeath, J., Galton, M. (2010). Re-inventing schools, reforming, teaching: From political vision to classroom reality, London, Routedge. https://doi.org/10.4324/9780203840344.

11. Viziunea ANIS Romania digitala 2025. Retrieved from ANIS - Asociația Patronala a Industriei de Software si Servicii: https://bit.ly/3bJt8aT.

12. Bercu, A., Cigu, E., \& Nestian, S. A. (2020). Enhancing Innovation in Higher Education Institutions: Case of Romania. In Babić, V., \& Nedelko, Z. (Ed.). Handbook of Research on Enhancing Innovation in Higher Education Institutions (pp. 118-140). IGI Global. https://doi.org/10.4018/9781-7998-2708-5.ch006.

13. Ashraf, M., Hoque, R. (2016) An illustration of information communication technology (ICT)-mediated innovation-adoption-implementation in rural Bangladesh. Tékhne, 14(1), 45-51. https://doi.org/10.1016/j.tekhne.2016.04.003.

14. Donner, J., Toyama, K. (2009) Persistent themes in ICT4D research: Priorities for inter-methodological exchange. Durban, South Africa: 57th Session of the International Statistics Institute. Retrieved from Academia.edu: http://bit.ly/3vpeI7x.

15. Mrejeru, Cecilia-Cristina (2017) Tehnologia informației şi a comunicațiilor, Editura Rovimed. 2017. 56 p.

16. Tamaș Anca. (N.d.) 21 de meserii ale viitorului în domeniul resurselor umane. Retrieved from INACO: https://bit.ly/3ldU0mw.

Надійшла до редакції 12.06.2020

\author{
Ніколета ДОСПІНЕСКУ, \\ Октавіан ДОСПІНЕСКУ \\ Ясський університет іл. А. Й. Кузи (Рулунія)
}

\title{
Інформаційні технології для підтримки освіти під час COVID-19
}

Метою иього дослідження є синтез літератури, що спеціалізуеться на впровадженні інформаційно-колунікаційних технологій (IКT) в освітне середовище, з урахуванням переваг, недоліків та облежень, враховуючи попередні спроби пандемї COVID-19, а також поточні потреби, породжені сочіальною дистанцією. Ми враховуемо як навчальну, так $і$ технічну діяльність, необхідну для створення та підтрилки інтернет-платфорл для спілкування та оиінки. Той фбакт, шо нові технологї, пов'язані зі штучним інтелектол, робототехнікою, хмарними обчисленнями та блокчейном, швидко прогресують, змушуе Рулунію пришвидшити процес иифбової трансформацї відповідно до вимог Європейського Союзу. Відтепер кожна людина, а особливо молодь, повинна постійно вдосконалювати свої иифрові навички протягом усього життя. Насправді, прогрес у впровадженні технологій в освіту був незначнил. Молоді люди, як правило, більше користуються інтернетом для спілкування та менше для навчання. Поліпшення результатів у вихованні молоді може бути досягнуто лише шляхол інновацій викладацьких систел, заснованих на нових послугах, технологіях, колпетениіях викладачів, що встановлюють чітку навчальну мету. Окремі положення дулки иієї статті були представлені на ХХ Міжнародній конфберенијї з теоретично-практичної конферениї "Статистичні методи та інфборлаиійні технології для аналізу соціально-еконолічного розвитку", яка відбулася 
21 травня 2020 року в Хлельницькому університеті управління та права ілені Леоніда Юзькова.

Ключові слова: інфорлаційно-колунікаційні технологї, медіапедагогіка, COVID-19, інтернет-освіта, соціальне дистаниіювання. 